\title{
OS MISTÉRIOS DE PAULO LEMINSKI
}

\author{
Ricardo Gessner* \\ Universidade Estadual de Campinas
}

\begin{abstract}
Resumo: Ademais de recorrências estilísticas na poesia de Paulo Leminski (1944-1989), aspecto até o momento largamente estudado pela crítica especializada, também é possível identificar recorrências temáticas. Nesse sentido, este trabalho propõe-se a analisar e interpretar a temática do mistério, articulada em dois poemas: "rio do mistério", e "Suprassumo da Quintessência", publicados, respectivamente, em Distraídos Venceremos (1987) e La vie en close (1991). Com isso, serão feitos inicialmente uma análise e uma interpretação de cada poema, verificando em que medida há um diálogo entre eles e, desse modo, conseguir subsídios para constituir uma hermenêutica para o que pode significar a recorrência dessa temática e desenvolvê-la na análise e interpretação do poema "Adminimistério", também pertencente ao livro Distraídos Venceremos. Para desenvolver o trabalho, o ponto de partida serão os próprios textos poéticos, sendo que referenciais teóricos serão utilizados como apoio para o desenvolvimento da discussão, enfocando, principalmente, a obra ensaística do próprio Paulo Leminski, sobre o que o poeta pensa e desenvolve acerca da temática do mistério.
\end{abstract}

Palavras-chave: Literatura brasileira. Poesia Contemporânea. Paulo Leminski.

Me recuso a viver num mundo sem sentido.

Paulo Leminski

\section{Introdução}

Quando folheamos a obra poética de Paulo Leminski, em alguns momentos percebemos a recorrência de certas temáticas. E mais do que isso, parece que há uma retomada de um mesmo assunto em momentos e poemas diferente. Um desses casos se dá entre dois poemas: um sem título, publicado no livro Distraídos Venceremos (1987) e outro intitulado "Suprassumos da Quintessência", publicado no livro póstumo La vie en close (1991). Vejamos:

rio do mistério

o que seria de mim

se me levassem a sério? (LEMINSKI, 1987, p. 116)

\section{Esta obra está licenciada sob uma Creative Commons - Atribuição 4.0}

\footnotetext{
* Mestre em Teoria e História Literária pelo programa de pós-graduação do Instituto de Estudos da Linguagem, Unicamp; doutorando em Teoria e História Literária pela mesma instituição, sob orientação do Prof. Dr. Marcos Lopes. Atualmente também é professor colaborador na Universidade estadual do Norte do Paraná, campus de Jacarezinho - PR. E-mail: <rigessner@yahoo.com.br>.
} 
E, respectivamente:

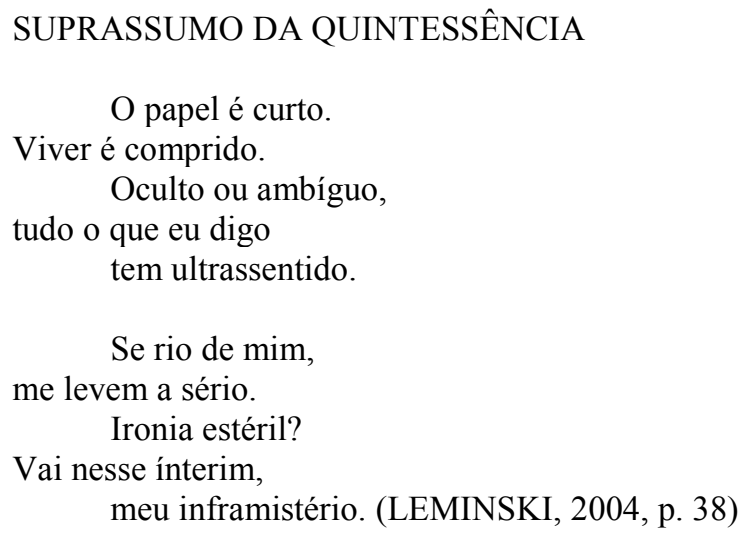

A possibilidade de relacionar os dois poemas não passou despercebida pela crítica. Fabrício Marques, no livro Aço em flor - A poesia de Paulo Leminski (2001), identificou e discutiu dentro de sua proposta investigativa, que é explorar as várias facetas estético-poéticas identificáveis na poesia de Leminski, principalmente no que tange o seu referencial intertextual:

Da obra poética, pretende-se apresentar quatro das possíveis dimensões que se
descortinam aos olhos do leitor. Assim, articula-se a poesia (enquanto concisão,
invenção, informação e consciência semiótica) com as ligações de Leminski com
uma forma oriental que teve seu auge no século XVII - o hai-kai; com a Tropicália
(1967-68); com a vanguarda concretista (meados dos anos 50 até fins dos 60); e com
a semiótica. Esta última dimensão, aliás, está intrinsecamente ligada à anterior,
como que complementando-a, pois a Poesia Concreta expressa a "consciência
intersemiótica e assimilação, pela criatividade, da Revolução industrial"
(MARQUES, 2001, p. 30)

Assim Fabrício Marques constitui o que Maria Esther Maciel, no prefácio do livro, chamou de "faces poliédricas": cada "face" seria representativa de uma "linha de força" específica, passível de ser identificada nessa poesia "multifacetada". Importante enfatizar que essas "faces" são interdependentes na poesia de Leminski e tornam-se identificáveis somente pelo corte analítico-crítico, como recurso para compreender como se constitui essa poesia.

Dentro desse contexto, Fabrício Marques apresenta e discute ambos os poemas. Segundo o autor, entre eles há uma "transformação" - o primeiro transforma-se no segundo que é índice de um aspecto constituinte da poesia de Leminski:

A transformação do poema não deixa dúvidas quanto a uma insistência no aporte metalinguístico, uma necessidade de explicação da poética do autor, acarretando na utilização frequente de recursos tais como a ironia e a metalinguagem enquanto fingimento poético. Como assinalado no poema, o "inframistério" é percebido justamente na ironia (Se rio de $\mathrm{mim} / \mathrm{me}$ levem a sério). Por outro lado, uma análise superficial levaria a concluir que o fato de ter aumentado o poema nesses dois exemplos seria um abandono do rigor. $\mathrm{Na}$ verdade, esse procedimento efetuado por 
Leminski pode significar que a concisão não tem a ver apenas com brevidade, mas também com exatidão: as palavras que explodem, mais-que-perfeitas, no céu dos cinco mil sentidos (MARQUES, 2001, p. 93)

Ou seja, a "transformação" indica uma "insistência metalinguística" implicada numa reescrita. Isto é, o que caracteriza a recorrência do tema "mistério" é que os poemas são reescritos. Essa reescrita, por sua vez, é índice de uma preocupação do próprio poeta Paulo Leminski em constituir com "exatidão" o seu texto poético: utilizar-se das palavras "maisque-perfeitas" para constituir sua poesia com perfeição. Tal "exatidão", por sua vez, caracterizaria uma das "faces" dessa poesia "poliédrica", que seria a face do "rigor". É uma leitura que responde aos propósitos analíticos de Fabrício Marques, em delimitar a constituição estética da poesia leminskiana. Seu estudo enfoca as relações intertextuais, que são vertidas em "linhas de força".

Dessa leitura podemos depreender que "rio do mistério" e "Suprassumos da Quintessência" seriam o mesmo poema, aspecto que revelaria uma atitude atenta do poeta ao escrever sua poesia. Por outro lado, não entram em discussão os efeitos de sentido que cada poema pode constituir. Diante disso, é possível problematizar a relação entre eles. Talvez olhando para os efeitos de sentido que cada poema constitui, seja possível levar a discussão para outros caminhos que possam contribuir com outras maneiras de entender a poesia de Leminski. Se há uma recorrência da temática do mistério, o que isso significa em termos de possibilidade hermenêutica?

\section{Dois mistérios}

No ano de 1963 Leminski participou da Semana Nacional de Poesia de Vanguarda, realizada em Belo Horizonte sob organização de Affonso Romano de Sant'Anna. Foi quando o curitibano conheceu o trio concretista - os irmãos Augusto e Haroldo de Campos, e Décio Pignatari - contato que lhe rendeu a oportunidade de estrear como poeta no ano seguinte, em 1964, na revista Invenção, mantida pelos poetas concretos. Daí em diante Leminski passa a se preocupar em constituir sua própria dicção poética. Para tanto, articula um referencial amplo e eclético, que abrange não apenas o Concretismo, mas perpassa o Tropicalismo, contracultura, poesia Beat, haikai japonês; a Semiótica de Charles Sanders Peirce, "pensamento" zen, para elencar alguns. Trata-se de um período que se estende de 1964 até o início da década de 1980, quando Leminski publica em edições independentes dois livros: Não fosse isso e era menos, não fosse tanto e era quase e Polonaises.

Basicamente é um período de formação, em que o poeta se preocupa em constituir 
sua individualidade poética. Isso é identificável nas cartas enviadas a Régis Bonvicino, que compreendem uma extensão de tempo entre meados de 1976 até o início de 1980. Esse período de formação, por sua vez, recebe seu coroamento em 1983, com a publicação de Caprichos e Relaxos, seu primeiro lançamento através de uma grande editora: a Brasiliense. Naquele momento o livro the rendeu considerável popularidade, ao vender um número expressivo de exemplares e ter sucessivas reimpressões (VAZ, 2001).

Por outro lado, o mesmo êxito de vendas não se deu com Distraídos Venceremos (1987) seu segundo livro de poemas editado pela Brasiliense. Quanto a essa divergência, é possível associá-la a uma mudança de perspectiva por parte de Leminski, de um livro ao outro. Enquanto que em Caprichos e Relaxos parece ser o momento de conquista e consolidação de sua própria dicção poética - a síntese entre rigor formal e acessibilidade, aspecto largamente explorado pela crítica atual -, em Distraídos Venceremos há um propósito bem delimitado:

Nas unidades de Distraídos Venceremos (1987), resultado do impacto da poesia de Caprichos e Relaxos (1983) sobre a fina e grossa cútis da minha sensibilidade lírica [...], acredito ter atingido um horizonte longamente almejado: a abolição (não da realidade, evidentemente) da referência através da rarefação (LEMINSKI, 1987, p. 07)

Compreender, explicar e interpretar esse propósito é tarefa realizada noutra ocasião e foge do escopo deste artigo; por outro lado, mostrar e enfatizar essa mudança de foco pode servir como indicativo de que em Leminski as coisas nem sempre são o que parecem. Digo isso tendo em vista do constructo crítico ainda predominante sobre sua poesia, de que é o resultado da ação biográfica do autor: uma persona atuante nos meios culturais e midiáticos, que se articula de um repertório cultural e intelectual sofisticado, erudito, eclético, associado a um comportamento debochado, (auto)irônico, muitas vezes humorístico, afeito a cultura pop. Nesse sentido Paulo Franchetti constrói seu argumento, de que essa poesia perde atualmente sua força lírica devido à falta da figura biográfica do autor:

\footnotetext{
Lida hoje, a poesia de Leminski se ressente da ausência do seu criador. A consideração objetiva dos seus gestos verbais nem de longe permite ter uma ideia da energia que os animava, e que provinha daquilo que não era texto: a construção de uma figura pública de alto poder de sedução, graças ao brilho da inteligência, ao ecletismo de princípios e procedimentos e à eficácia da carreira de poeta $p o p$, capaz de transitar à vontade entre os mass media e os redutos da cultura erudita. Sua poesia tinha assim um caráter essencialmente performático, que já tornava efetivo aquilo que apresentava como ideal futuro: "vai chegar o dia / em que tudo o que eu diga / seja poesia” (FRANCHETTI, 2007, p. 287-288)
}

Nota-se a preponderância dada, até o momento, tanto na figura biográfica de 
Leminski quanto em sua capacidade de articular um repertório amplo e eclético. Porém permanece em segundo plano as possibilidades hermenêuticas dessa poesia, que talvez aí esteja outra força lírica e possa abrir outros caminhos de estudos. Vejamos o poema seguinte, sem título, publicado em Distraídos Venceremos:

$$
\begin{aligned}
& \text { rio do mistério } \\
& \text { o que seria de mim } \\
& \text { se me levassem a sério? (LEMINSKI, 1987, p. 116) }
\end{aligned}
$$

Numa leitura rápida, o poema parece condensar os fatores apontados anteriormente: o eu-lírico zomba de si mesmo indagando sobre a seriedade que não lhe é dedicada. $\mathrm{O}$ resultado: um efeito auto-irônico ao ver-se incompreendido, e zomba dessa situação. Mas o poema não se esgota aí. Vejamos com mais atenção.

Há um ludismo anagramático (STAROBINSKI, 1974) que permeia todo o poema: o termo rio perpassa pelo termo "mistério" no primeiro verso: mistéRIO; também perpassa pelo segundo verso: “O que seRIa de mim”; e pelo último termo do poema: "séRIO". Isso pode ser compreendido como um recurso icônico (PEIRCE, 2011) ao constituir o movimento de um rio, com o seu percurso. Porém ele, o rio, é ocultado nesses anagramas e por isso se constitui no "rio do mistério", ao qual no primeiro verso é estabelecido como interlocutor: "você, rio do mistério, o que seria de mim...”. E o que isso significa? Significa que levá-lo a sério pode revelar aspectos menos evidentes, que passam despercebidos sob os olhos que seguem o curso mais evidente da zombaria, incluindo, talvez, o próprio eu-lírico, que se vê como um desconhecido por si mesmo.

Aqui vale lembrar o epíteto cunhado por Leyla Perrone-Moisés, quando chama o poeta de "samurai-malandro". Podemos visualizar ambas as facetas: o lado "samurai" se enquadraria na sofisticação dos jogos formais, das ambiguidades, que requerem maior atenção por parte do leitor; o lado "malandro" se enquadraria no efeito humorístico e auto-irônico que o poema, de imediato, constitui. Porém é conveniente dar um passo além e indagar: o que isso tudo significa? Mais especificamente: o que isso pode significar tendo em vista a temática do "mistério"?

Vejamos: será que o termo "rio" é utilizado apenas como o substantivo que designa as águas que correm por determinado percurso, fazendo, assim, do "rio" um interlocutor? Ou será o termo empregado como verbo "rir", na primeira pessoa do singular do tempo presente, fazendo do "mistério" um objeto de riso? Ambos os efeitos são válidos e levam ao mesmo lugar: a indagação final, sobre ser "levado a sério". E é ela que se sobressai no poema. Se no primeiro verso há uma dubiedade gerada pelo que está dito - o "rio", que pode ser substantivo 
ou verbo -, com a indagação constitui-se uma dubiedade pelo que não está dito: a expectativa de uma resposta: "O que seria de mim se me levassem a sério?". Abrem-se ao leitor possibilidades de preencher esse "mistério": não seria nada, pois a jocosidade lhe é inerente e se lhe for retirada anularia sua "individualidade"; ou sua individualidade seria outra, incognoscível ou imperceptível para aqueles que não lhe levam a sério. E, sendo assim, que outra coisa seria? Antes de responder a qualquer dessas perguntas, resolvamos antes um impasse.

Note que, do modo com foi apresentado, o poema possui duas ambiguidades: uma no termo "rio", outra na expectativa da resposta à indagação. A primeira se constitui no que está dito, a outra se constitui pelo não-dito.

A dubiedade do termo "rio", como se disse, leva a um mesmo lugar: tomando-o como substantivo ou como verbo, chega-se à mesma pergunta sobre ser "levado a sério". O ganho hermenêutico em revelá-la é estilístico, pois evidencia a sutileza no manuseio com a linguagem. Por outro lado, a dubiedade gerada pela expectativa da resposta pode mudar o curso de compreensão do poema. Se a resposta for "nada", isso significa que o eu-lírico continuaria sendo quem ele é, ou melhor, o que ele aparenta ser, resultando numa sobreposição da aparência: o olhar sobre ele não mudaria; se a resposta for "outra coisa", caberia compreender o que seria essa "outra coisa". Em suma, cada uma dessas respostas reflete o lugar de onde provavelmente partiram: a primeira corresponde a um olhar externo, que, por sua vez, percebe o que é externo, as aparências, que no poema se manifesta como jocosidade; a segunda resposta corresponde a um olhar interno, que permitiria revelar aspectos até então desconhecidos ou despercebidos, não manifestados na aparência. Em última instância, se a ambiguidade do termo "rio" é irrelevante para uma compreensão mais aprofundada do poema, podemos fazer disso uma espécie de analogia com a pessoa do eulírico: essa ambiguidade se manifesta no que está dito, no plano explícito, portanto; o mesmo se dá com o que é aparente a respeito da caracterização da individualidade desse eu-lírico. Ou seja, a ambiguidade do que é aparente não muda o produto final do poema, da mesma forma que a percepção da personalidade manifestada desse eu-lírico não revela o que seria sua "verdadeira" individualidade. Tudo são aparências. Portanto, levar-lhe a sério revelaria outros aspectos menos evidentes, implícitos e, até mesmo, desconhecidos.

A partir daqui é possível dizer que o "mistério" nesse poema é esse "outro eu" que não se revela nas aparências e permanece desconhecido. O "riso" do início do poema não precisa ser, necessariamente, um riso de jocosidade em que o eu-lírico se diverte com a 
suposição de ser levado a sério; pode ser um riso que expressa um certo medo ou incômodo diante do desconhecimento sobre si mesmo, ou até mesmo diante do medo em conhecer a si mesmo; ou, ainda, diante da incompreensão dos outros. Portanto, o poema pode revelar uma auto-ironia, mas não se resume a isso.

Por todo o livro de Distraídos Venceremos é possível identificar vários poemas que trazem a temática do "mistério", por exemplo, o poema "Adminimistério, o que pode ser índice de um projeto maior. Porém a discussão torna-se curiosa ao constatar que na obra seguinte, La vie en close, livro póstumo publicado em 1991, há um poema que parece ser uma continuação do poema discutido anteriormente:

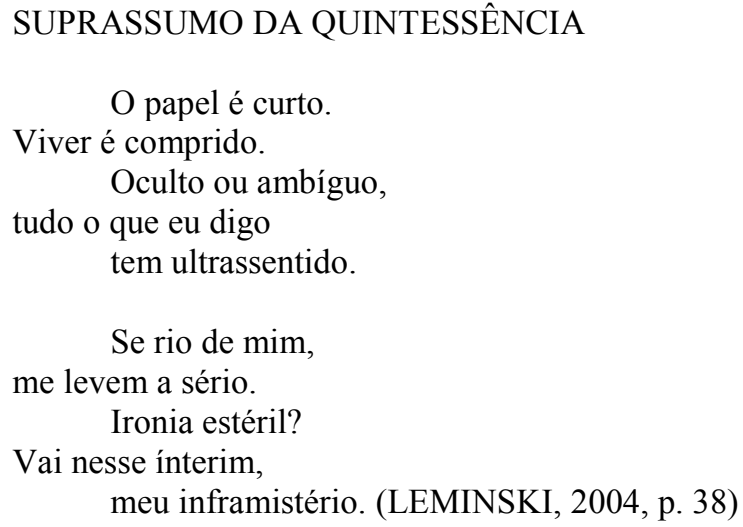

Os dois primeiros versos da segunda estrofe retomam diretamente o poema anterior: "Se rio de mim, / me levem a sério" é quase um eco do poema "rio do mistério / o que seria de mim / se me levassem a sério?”. Mas a diferença é que, antes, o objeto de riso era o próprio "mistério", projetando-se numa indagação; agora, o objeto de riso é si próprio constituindo-se numa afirmação: "se rio de mim, / me levem a sério". Isso gera algumas perguntas: quando o eu-lírico ri de si mesmo é para ser levado a sério, contrariando sua atitude jocosa? Ou o seu riso é que deve ser levado a sério? Ou, ainda, será uma armadilha para o interlocutor se perder numa rede de (im)possibilidades? E ao encarar esses versos como armadilha, qual caminho seria possível seguir?

Em primeiro lugar há uma oposição entre os dois últimos termos de cada estrofe "ultrassentido" e "inframistério", respectivamente -, gerada pelo prefixo morfológico de cada um.

"Ultra" designa o que está para além de, que transcende; associado ao termo "sentido", o neologismo designa dizeres que não se esgotam em sua acepção literal, constituindo outros sentidos que vão além do imediato. "Ultrassentido", portanto, são as ambiguidades e os sentidos ocultados que possuem os "dizeres" do eu-lírico: "Oculto ou 
ambíguo, / tudo o que eu digo / tem ultrassentido" ( $3^{\circ}, 4^{\circ}$ e $5^{\circ}$ versos). São sentidos que vão além do mais imediato e aparente. Esse recurso se constitui para dar conta do descompasso registrado nos dois primeiros versos do poema: "O papel é curto. / Viver é comprido". O descompasso entre "papel" e "viver" pode ser entendido como sendo a impossibilidade de registro das vivências, das experiências e da própria vida em sua completude, pois não cabem nas restrições exigidas pelo "papel”. Em outras palavras: as vivências abarcam uma multiplicidade de eventos impossíveis de serem registrados exclusivamente pela linguagem verbal, no papel. Por isso "o viver é comprido" em relação ao "papel”, que é "curto". Para contornar essa limitação, o eu-lírico forja um dizer que tem "ultrassentido", que permite fixar com inteireza o registro de suas experiências de vida.

"Infra" designa algo que está abaixo de, aquém de. Numa primeira leitura isso tem relação com o descompasso entre o "rir de si mesmo" e o "ser levado a sério", registrados nos primeiros versos dessa estrofe: "Se rio de mim, / me levem a sério", como se houvesse uma individualidade aquém das aparências, mais profunda e que não se manifesta na superfície. Com isso retornamos ao mesmo problema levantado no início da análise desse poema: quando o eu-lírico ri, o riso se projeta na individualidade, que deve ser levada sério contrariando sua aparência jocosa, ou é o próprio riso que deve ser levado a sério? Ou será uma armadilha para desviar a compreensão do interlocutor?

Entre o "rir de si mesmo" e o "ser levado a sério" a pergunta que coloco é: quem é, realmente, esse eu-lírico? Esse é o "mistério". No poema, é “infra”, pois não aparece, não é evidente. O eu-lírico carrega essa pergunta - esse mistério - sem enunciá-lo. E logo na primeira estrofe menciona sentidos ocultos em seus dizeres: "oculto ou ambíguo / tudo o que eu digo / tem ultrassentido" ( $3^{\circ}, 4^{\circ}$ e $5^{\circ}$ versos $)$.

Se o eu-lírico ri de si mesmo, bastaria esse riso para caracterizar sua individualidade? Parece que não, já que o riso é uma percepção exterior e não reflete nem demonstra, necessariamente, quem ele é. Por outro lado será cabível falar em individualidade como algo pronto? Noutros termos, a individualidade existe por si só, se auto-constitui, ou é ela fruto de um olhar externo, de uma "alteridade"? O poema nos deixa sem resposta, pois é justamente nessa alternância, ou seja, nesse "ínterim" ( $8^{\circ}$ verso) que segue seu "inframistério".

Note que é justamente um movimento de alternância ("ínterim”) que perpassa todo o poema: alterna-se o "papel curto" e o "viver comprido"; os dizeres tem "ultrassentidos" que são ambíguos ou ocultos; o "rir de si mesmo" e o "ser levado a sério" em contraposição a dúvida de uma "ironia estéril", até culminar no $9^{\circ}$ verso - nesse “ínterim” -, ou seja, nessa 
alternância, que dá seguimento ao seu "inframistério". Isso nos mostra que é a alternância que fundamenta todo o poema; um movimento de ir e vir, um movimento pulsativo. E a pulsação é o movimento que dá vida. É a alternância que mantém vivo esse eu-lírico. Entre o movimento de alternância, o momento em que se estabelece a relação de um estado a outro é um fator interessante de ser pensado. Ou seja, agora retornando a discussão do poema, a individualidade não se constitui per se, assim como não é somente fruto de uma alteridade: a individualidade se constitui na relação alterna entre os dois fatores. É sobre isso que versam os dois poemas: a relação alternada entre o indivíduo visto por si mesmo, em contraposição a um olhar externo: a diferença entre "rir de si mesmo" e "ser levado a sério", constituindo uma individualidade.

Aqui podemos ressaltar a diferença entre os dois poemas: em "rio do mistério / o que seria de mim / se me levassem a sério?" o eu lírico se coloca no lugar de objeto do riso, o efeito imediato é de que os outros não lhe levam a sério. Talvez isso aconteça por conta do próprio eu-lírico, que se auto-ironiza e permite constituir esse efeito. Mas até que ponto a indagação é ela mesma uma auto-ironia, como pareceu ser numa leitura imediata e superficial? Até que ponto não serve de apelo ou como um meio para realizar uma autorreflexão, que por sua vez se torna mais evidente no poema "Suprassumos da Quintessência"? O "mistério", portanto, é a busca pela compreensão da própria individualidade.

\section{Os mistérios de Paulo Leminski}

A temática do mistério não é algo isolado na obra poética de Paulo Leminski. No livro Distraídos Venceremos não são poucos os poemas que versam sobre o assunto, e o mesmo se pode dizer de La vie en close. É uma preocupação recorrente e pode indicar que seus poemas não se resumem em exercícios estilísticos, nem numa busca por uma dicção própria. Leminski quando escreve poesia, também pensa na vida, pensa em si mesmo, no lugar que ocupa e sente que ocupa no mundo, como se estivesse à procura de dar sentido à vida, algo natural da condição humana. Não é à toa que seu último livro intitula-se $O$ exestranho, cuja nota introdutória traz esses dizeres:

\footnotetext{
Este livro de poemas, que ia se chamar $O$ ex-estranho, expressa, na maior parte de seus poemas, uma vivência de despaisamento, o desconforto do not-belonging, o mal-estar do fora de foco, os mais modernos dos sentimentos. Nisso, cifra-se, talvez, sua única modernidade. (LEMINSKI, 1996, p. 19).
}

Ou seja, se os poemas expressam esse sentimento de not-belonging, de não pertencer, 
de não ser aceito em lugar algum, constituem-se, por outro lado, como possibilidade de delimitar seu próprio espaço e de nele se encontrar.

Aliás, essa temática vai além de sua obra poética e também está presente em sua obra ensaística. A busca ou atribuição de sentido é discutida, por exemplo, no ensaio "O Tema Astral”, publicado no volume Ensaios e anseios crípticos (2012b). Leminski começa falando sobre a associação que muitos poetas fazem entre o céu estrelado e a poesia, em que tentam registrar uma correspondência entre o "céu estrelado" e a "página escrita". Por outro lado há uma distância, um espaço "entre o mundo físico e o mundo totalmente humano do signo, isto é, da cultura" (LEMINSKI, 2012b, p. 77). Noutros termos, o "céu” corresponde à Natureza; a página, ao signo e, por extensão, ao Humano. O "mundo humano" é o dos significados. Não porque os humanos habitam um mundo que possui significado per se, mas é porque os humanos têm a capacidade de atribuir uma significação ao que a priori não tem. Dessa forma, a distância entre o "mundo físico" e o "mundo humano" diminui a partir do momento em que há atribuição de significado, pois desse modo passa a pertencer ao "mundo totalmente humano do signo". "Nenhuma forma existe no céu. Nosso olhar é que organiza as estrelas em constelações" (LEMINSKI, 2012b, p. 78). E mais do que isso:

\footnotetext{
$\mathrm{O}$ céu tem uma mensagem para nós. Mas essa mensagem não vem do céu. Vem do nosso condão de dar significado às coisas, nomes aos bois, formas de constelação e aglomerados de estrela.

Vem do nosso desejo de viver um mundo totalmente humano, cultural, sígnico. A ênfase deve ser colocada num gesto primordial do home levantando o rosto para o céu estrelado, na noite primordial em que se fundaram os significados e uma vida propriamente humana começou.

[...] Logo estão vendo o brilho do signo e do significado contra o fundo indiferente e insignificante do firmamento estrelado (LEMINSKI, 2012b, p. 79-80).
}

A relação entre a capacidade humana de atribuir sentidos com o mistério reside na analogia entre "céu” e "página": "Essa comparação céu-página é, misteriosamente, adequada. Misteriosamente quer dizer: essa adequação tem mistério, um demônio dentro dela" (LEMINSKI, 2012b, p. 76). Ou seja, é a categoria de "mistério" que caracteriza e justifica a relação entre "céu” e "página", entre Natureza e Humano. "Mistério" é o sentido atribuído e constituído entre as duas instâncias. Isso fica mais evidente noutro ensaio, publicado na mesma coletânea supracitada. Vejamos:

\section{BUSCANDO O SENTIDO}

O sentido, acho, é a entidade mais misteriosa do universo.

Relação, não coisa, entre a consciência, a vivência e as coisas e os eventos.

$\mathrm{O}$ sentido dos gestos. O sentido dos produtos. O sentido do ato de existir.

Me recuso (sic) a viver num mundo sem sentido.

Estes anseios/ensaios são incursões em busca do sentido. 
Por isso o próprio da natureza do sentido: ele não existe nas coisas, tem que ser buscado, numa busca que é sua própria fundação.

Só buscar o sentido faz, realmente, sentido.

Tirando isso, não tem sentido. (LEMINSKI, 2012a, p. 13)

Esse texto é uma espécie de introdução ao volume Ensaios e anseios crípticos, porém a reflexão feita pode iluminar e corroborar alguns aspectos que nos interessam. $\mathrm{O}$ "sentido" é caracterizado como a relação entre "a consciência, a vivência", e "as coisas e os eventos", isto é, entre fatores humanos e naturais, como discutido no texto anterior. Por ser uma relação, não se encontra em nenhum desses dois polos: não está nas coisas e o ser humano tem apenas a capacidade de constituí-los. É nessa interação, portanto que deve ser buscado o "sentido": "ele não existe nas coisas, tem que ser buscado, numa busca que faz, realmente, sentido". Ou seja, o gesto de busca fundamenta a criação de sentidos.

Cada ser humano é livre para traçar a sua própria busca pelos "sentidos", seja para justificar sua existência, seja para conhecer, constituir sua própria individualidade ou o lugar que ocupa no mundo. No caso de Leminski, essa busca se fundamenta na prática da escrita: "Me recuso a viver num mundo sem sentido. Estes anseios/ensaios são incursões em busca do sentido". Ou seja, seus poemas também podem ser englobados nesse sentimento de "anseio", não se esgotando, em termos de análise, em jogos lexicais ou reflexões metalinguísticas. Obviamente é um fator que deve ser problematizado, uma perspectiva não exclui a outra. Tudo deve ser discutido com atenção, considerando as particularidades de cada caso.

É sintomático a maneira como Leminski caracteriza a categoria de sentido: "é a entidade mais misteriosa do mundo". Ou seja, trata-se de uma "entidade" que, por sua vez, carrega consigo um "mistério". Lembremos que no texto anterior Leminski disse que a relação entre "céu-página" - Natureza e Humano - era "misteriosa", pois carregava consigo um "demônio". O termo "demônio", por sua vez, advém da língua grega: daimon, que significa "divindade", “espírito" e, por extensão, "entidade”. A caracterização é a mesma nos dois textos. O mistério é a alma do sentido.

Com isso é possível desenvolver uma discussão levando em conta outro poema, pertencente ao livro Distraídos Venceremos. Vejamos:

\title{
ADMINIMISTÉRIO
}

\author{
Quando o mistério chegar, \\ já vai me encontrar dormindo, \\ metade dando pro sábado, \\ outra metade, domingo. \\ Não haja som nem silêncio, \\ quando o mistério aumentar. \\ Silêncio é coisa sem senso,
}




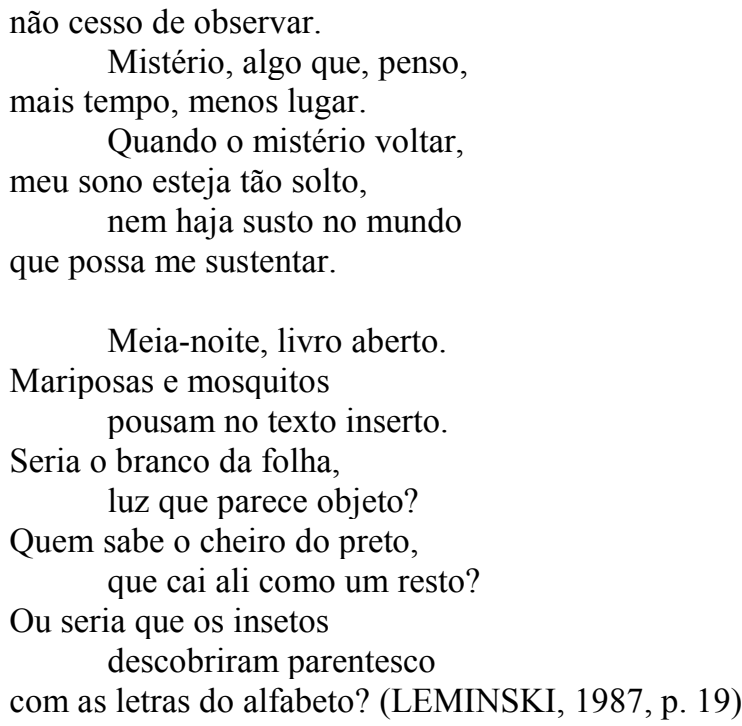

Sob um critério didático, o poema pode ser dividido em quatro partes, cada uma correspondendo a um momento específico de como se dá a relação entre o eu-lírico e o "mistério".

A primeira estrofe engloba três desses momentos. O primeiro se constitui do $1^{\mathrm{o}}$ verso ao $4^{\circ}$ verso, constituindo um momento de expectativa: espera-se a chegada do "mistério": "quando o mistério chegar". O segundo momento compõe-se do $5^{\circ}$ ao $10^{\circ}$ versos e retrata o momento em que o "mistério" está presente, implicando numa ação: "quando o mistério aumentar". O terceiro momento se constitui do $11^{\circ}$ verso ao $14^{\circ}$, em que se retrata uma expectativa de retorno do mistério, que já se foi: “quando o mistério voltar", recobrando um estado similar ao do primeiro momento, também de expectativa, compondo um círculo de "chegar/aumentar/voltar". O quarto momento corresponde a segunda estrofe, em que se retrata a própria categoria de "mistério". Vejamos com mais detalhes.

No primeiro momento é estabelecido um ponto de encontro entre o eu-lírico e o "mistério", mas trata-se de um espaço de tempo: "de sábado para domingo", do último dia da semana para o primeiro, o que sugere um encerramento de um ciclo ou etapa, e início de outra. Desse modo não é gratuito que no terceiro momento, como vimos, fica em aberto a possibilidade de retorno do "mistério", compondo o movimento circular. Outro aspecto que chama a atenção é de o eu-lírico estar "dormindo", isto é, encontra-se noutro estado de consciência cuja percepção não se dá diretamente pelos sentidos, assim como a atuação de suas faculdades intelectuais é restrita. É como se estivesse numa posição meditativa.

O segundo momento é quando o "mistério" encontra-se presente: "Não haja som nem silêncio, / quando o mistério aumentar. / Silêncio é coisa sem senso, / não cesso de observar. / mistério, algo que, penso, / mais tempo, menos lugar" (ênfase minha). Fala-se 
sobre não haver "som" nem "silêncio", que são categorias que classificam aspectos da realidade. Ao negar a existência de ambas, o eu-lírico afasta-se do pensamento articulado e constitui um gesto mais sutil, de superar os contrários: tanto "som" quanto "silêncio" são abolidos. É um dado que reforça a suspeita de que esse eu-lírico se encontre num estado de consciência meditativo. Porém em seguida há um paradoxo: "silêncio é coisa sem senso, / não cesso de observar": para observar é necessário estar atento, noutras palavras, é preciso pensar articuladamente. Talvez represente um momento em que o estado meditativo do eu-lírico é interrompido. Nos versos seguintes, "mistério, algo que, penso, / mais tempo, menos lugar", também há um paradoxo, agora entre as categorias de "tempo" e "lugar". Quanto mais o eulírico "pensa" - e aqui nossas suspeitas se confirmam: ele pensa articuladamente - mais ele se afasta de uma compreensão sobre o "mistério", por isso é "algo sem censo".

No terceiro momento o eu-lírico fala de um "sono solto", ou seja, um estado de consciência similar ao que encontramos no primeiro, quando estaria "dormindo": "Quando o mistério voltar, / meu sono esteja tão solto, / nem haja susto no mundo / que possa me sustentar". Nenhum "susto", ou seja, nenhuma intempérie poderá interromper seu estado de consciência. Cabe observar um jogo anagramático entre "susto" e "sustentar": SUSTo e SUSTentar, compondo uma falsa etimologia, mas constituindo um efeito de correspondência entre os termos. Visto que "susto" é um obstáculo para o pensamento meditativo, o anagrama sugere que o indivíduo "desperto", que pensa articuladamente, é "sustentado", isto é, carregado, pelo "susto", ou seja, pelo erro: as faculdades intelectuais submetem a uma compreensão dentro de categorias convencionais.

A segunda estrofe compreende o quarto momento. Articula-se integralmente a categoria de "mistério", e o momento em que está presente: "Meia-noite, livro aberto. / Mariposas e mosquitos / pousam no texto incerto. / Seria o branco da folha, / luz que parece objeto? / Quem sabe o cheiro do preto, / que cai ali como um resto? / Ou seria que os insetos / descobriram parentesco / com as letras do alfabeto?". O tempo na estrofe é "meia-noite", o mesmo que permanece sugerido nos primeiros versos da primeira estrofe: "de sábado para domingo". É o ponto de encontro entre eu-lírico e "mistério", é um instante. O núcleo da estrofe, por sua vez, caracteriza-se por um evento: o "pouso" de "mariposas" e "mosquitos" numa "folha" com um "texto incerto". A partir desse evento, o eu-lírico elenca uma série de questionamentos que tem como base comum o motivo que ocasionou o "pouso". Foi por causa do "branco da folha"? Do "cheiro do preto" da tinta que está na folha? Ou devido a um possível "parentesco" entre "insetos" e "letras do alfabeto"? 
"Mariposas" e "mosquitos" podem ser compreendidos como uma representação icônica de dois olhos que "pousam" no texto. Nesse sentido, observe a simetria fônica entre os termos: o fonema /i/ que se destaca na primeira parte de marIposas e na segunda parte de mosquItos; o fonema /ô/ que se destaca na segunda parte de maripOsas e na primeira parte de mOsquistos. A simetria constitui-se em ícone de dois olhos que observam o "texto incerto": marIpOsas e mOsquItos.

Se o "texto é incerto", abrem-se algumas possibilidades de compreensão: é um texto que está sendo escrito pelo próprio eu-lírico? É um texto inacabado? Ou esta sendo interpretado pelo eu-lírico? A resposta mais adequada parece ser uma síntese dessas possibilidades: o eu-lírico, enquanto leitor, constrói seu próprio texto na medida em que elabora sua própria interpretação. O texto é incerto porque pode variar de acordo com os "olhos" que nele "pousam", de acordo com o leitor que projeta significações, baseadas em seu leque de experiências. Em última instância, esse eu-lírico busca um sentido.

O "livro aberto" funciona como metáfora da própria realidade objetiva e mundana, que sob os olhos indagadores do ser humano, é passível de adquirir significação. Os "olhos" que "pousam" na realidade buscam uma compreensão. Nessa tentativa, o que se faz é atribuir, e não extrair, sentidos.

O "mistério" nesse poema é a busca pelo sentido, ou seja, pela compreensão da realidade. Não é um processo necessariamente simples, mas representa uma característica inerente ao ser humano, que é sua capacidade de atribuir significados. É esse mesmo ímpeto que o leva a fazer ciência, filosofia, poesia. "Adminimistério" condensa essa ânsia: ad mim mistério, a vinda do mistério, dos questionamentos, a tentativa de administrá-lo e organizá-lo.

\section{Considerações finais}

Ao contrário do que disse Paulo Franchetti, lida hoje e com atenção, a poesia de Paulo Leminski pode revelar uma força lírica autônoma, independente da figura biográfica do poeta. Isso não se constitui numa regra válida e aplicável para toda sua poesia, mas deve ser problematizado em cada caso, sendo possível identificar momentos mais fortes em suas possibilidades hermenêuticas, outros mais fracos.

A categoria de "mistério" nos poemas analisados, portanto, significa a busca de um significado, seja para a vida, para a constituição de uma individualidade, seja para a relação entre indivíduo e mundo. Isso não é uma regra absoluta e geral; trata-se, aqui, exclusivamente de uma proposta hermenêutica que não pretende excluir outras possibilidades.

Etimologicamente, "poesia" vem do grego: poiesis. Em grego poiesis também é 
utilizado como verbo: significa "fazer", "produzir", “constituir", "criar". Isso significa que fazer poesia é produzir, criar, sentidos. Ou seja, pode se tornar um meio para atribuir sentido ao que a princípio não teria. No caso dos poemas analisados, portanto, o mistério é o ato de produzir sentido, de fazer poesia, mas não de uma poesia como mero objeto artístico, mas daquilo que dá sentido ao indivíduo em relação aos seus anseios.

Podemos depreender daí que Leminski, ao escrever seus poemas, busca mais do que constituir sua dicção poética, Leminski busca um sentido para sua vida: "me recuso a viver num mundo sem sentido", como diz em seu ensaio supracitado. Consequentemente, o poeta também se recusa a viver num mundo sem poesia, e por isso faz poesia.

\section{Referências}

FRANCHETTI, Paulo. Pós-tudo: a poesia brasileira depois de João Cabral. In: Estudos de literatura brasileira e portuguesa. Cotia, SP: Ateliê, 2007, p. 253-289.

LEMINSKI, Paulo. Distraídos Venceremos. São Paulo: Brasiliense, 1987.

. Buscando o sentido. In: . Ensaios e anseios crípticos. São Paulo: Editora Unicamp, 2012a.

. O tema astral. In: . Ensaios e anseios crípticos. São Paulo: Editora Unicamp, $2012 b$.

. La vie en close. São Paulo: Brasiliense, 2004.

O ex-estrenho. São Paulo: Iluminuras, 1996.

MARQUES, Fabrício. Aço em flor - A poesia de Paulo Leminski. Belo Horizonte: Autêntica, 2001.

PEIRCE, Charles Sanders. Semiótica. São Paulo: Perspectiva, 2011.

STAROBINSKI, Jean. As palavras sob as palavras. São Paulo: Perspectiva, 1974.

VAZ, Toninho. Paulo Leminski: o bandido que sabia latim. Rio de Janeiro: Record, 2001.

[Recebido em outubro de 2015 e aceito para publicação em dezembro de 2015]

\section{The mysteries of Paulo Leminski}

Abstract: Actually Paulo Leminski's (1944-1989) poetry is widely studied focusing its stylistic recurrences. In the other hand, there are thematic recurrences, aspect not so studied until now. Thus, this paper proposes to analyze and interpret the "mystery" theme, articulated in two poems: "rio do mistério" and "Suprassumo da Quintessência", respectively published in Distraidos Venceremos (1987) and La vie en close (1991). First of all, it will be made an analysis and interpretation of each poem, discussing a possible dialogue between them and, thereby, get subsidies to constitute a hermeneutic for what it might mean the recurrence of 
this theme, and use in an analysis and interpretation of the poem "Adminimistério", also present in Distraidos Venceremos. The poems will be the starting point; theoretical frameworks will be used as support for the development of the discussion, focusing mainly on the essayistic work of Paulo Leminski, on what he thinks about the "mystery" theme.

Keywords: Brazilian Literature. Contemporary poetry. Paulo Leminski.

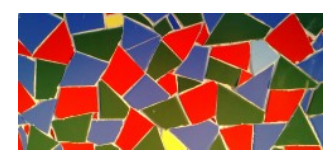

